\title{
Assessment of Zinc- alfa2 Glycoprotein (ZAG) and Lipase Maturation Factor 1 (LMF1) Concentration in Children with Chronic Kidney Disease
}

\section{Dagmara ROSZKOWSKA-BJANID ${ }^{1}$, Katarzyna DYGA ${ }^{1}$, Elżbieta ŚWIĘTOCHOWSKA ${ }^{2}$, Omar BJANID ${ }^{3}$, Maria SZCZEPAŃSKA ${ }^{3}$}

${ }^{1}$ Pediatric Nephrology Ward, Independent Public Clinical Hospital No. 1 in Zabrze, Poland, ${ }^{2}$ Chair and Department of Medical and Molecular Biology, Faculty of Medical Sciences in Zabrze, Medical University of Silesia in Katowice, Poland, ${ }^{3}$ Department of Pediatrics, Faculty of Medical Sciences in Zabrze, Medical University of Silesia in Katowice, Poland

Received June 6, 2020

Accepted April 13, 2021

Epub Ahead of Print June 2, 2021

\section{Summary}

ZAG (zinc-a2-glycoprotein) - adipokine, may participate in the mechanism of malnutrition in chronic kidney disease (CKD) as cachexia factor. The transmembrane protein of the endoplasmic reticulum - lipase maturation factor 1 (LMF1) is necessary for the secretion and enzymatic activity of lipases and lowering triglycerides level. The aim of the study was to evaluate these markers - ZAG and LMF1, their potential importance in CKD in children. The study included 59 children and adolescents aged $10.7 \pm 5.0$ years with CKD. Compared with healthy children, serum and urine ZAG levels were higher in children with CKD. A similar relationship was obtained in the comparison of girls and boys between the above groups. We showed a reduced serum and urine concentration of LMF1 in children with CKD. Additionally, ZAG and LMF1 levels in children below 10 years of age and above 10 were no different. There was also no correlation between these markers and serum creatinine (except negative correlation of urinary ZAG), albumin, cholesterol, triglycerides. LMF1 concentration correlated positively with vitamin $D$ level in dialyzed patients. To conclude, elevated serum ZAG levels in children with CKD document that selective kidney damage results in the rise of ZAG concentration, however the specific role of this marker in malnutrition was not documented. Reduced serum LMF1 concentration in children with CKD, did not correlate with standard parameters used to assess lipid metabolism and severity of CKD. The usefulness of LMF1 as the marker of the lipid metabolism disturbances in children with CKD was not proven.

\section{Key words}

Children • Chronic kidney disease • Zinc-a2-glycoprotein (ZAG) • Lipase Maturation Factor 1 (LMF1) • Renal replacement therapy

\section{Corresponding author}

Maria Szczepańska, Department of Pediatrics, Faculty of Medical Sciences in Zabrze, Medical University of Silesia in Katowice, 3-Maja Street 13/15, 41-800 Zabrze, Poland. E-mail: szczep57@poczta.onet.pl, ializy_dzieciece_zabrze@poczta.onet.pl

\section{Introduction}

The main function of the kidneys is to ensure, through homeostasis of the extracellular fluid, an adequate and stable internal environment for the body's cells. Progressive chronic kidney disease (CKD) results in increasing disturbances in the volume and composition of this environment, with further clinical disorders, including the alterations of the cardiovascular system, and biochemical variations with the final clinical expression as uremic status. Despite spectacular advances in renal replacement therapy as well as in transplantation we are still far from being able to completely replace all complex kidney functions. Despite optimal therapy, the phenotype of patients with end-stage renal disease (ESRD) resembles the accelerated aging process (Kooman et al. 2013, Kooman et al. 2014).

The accumulation of uremic toxins causes, 
among others, chronic oxidative stress and the release of proinflammatory cytokines, which results in a predominance of biochemical catabolic pathways over anabolic, exhaustion of anti-aging mechanisms (e.g. decrease in fetuin and Klotho protein), and promotion of processes that stimulate senescence (such as hyperphosphatemia and activation of angiotensin II pathway) (Kooman et al. 2014). The effect of these complex and yet unrecognized disorders is a common phenotype for many serious chronic diseases, which consists of such changes as cachexia (e.g. reduction of muscle mass), a tendency to tissue fibrosis, calcium deposition in vessels with their hardening and endothelial dysfunction. A lot of evidence confirms this observation at $\mathrm{CKD}$, including telomere shortening and accumulation of advanced glycation (AGE) products in this disease (Kooman et al. 2014, Carrero et al. 2008, Stenvinkel et al. 2013).

Accordingly, the life expectancy of a CKD patient is significantly shorter than that of the general population, in dialysis children the reduction is even $40-60$ years! Mortality in the group of patients with end-stage renal disease (ESRD) is about 30x higher than in healthy children, and the survival rate after 10 years is $80 \%$, while after 20 years $-66 \%$. (Collins et al. 2008, Grothoff et al. 2002, McDonald and Craig 2004, Oh et al. 2002).

Since the publication of KDOQI recommendations for CKD (National Kidney Foundation 2002), and the dissemination of routine laboratory calculations for eGFR, there has been a significant increase in awareness of the growing incidence and prevalence of $\mathrm{CKD}$, and its increasing public health burden. Better recognition and awareness of the problem were reflected in a large number of studies devoted to, among others biomarkers in CKD. They allow for the early recognition of the disease and its individual components, as well as stratify the risk of its occurrence and therefore optimize prophylactic treatment. A biomarker is defined as a measurable and rational biological parameter that is an indicator of a physiological or pathological biological process or response to therapeutic intervention. To organize this dynamic field of scientific research and create a common conceptual framework, it was proposed to separate four categories of biomarkers in CKD (Shlipak and Day 2013):

- systemic biomarkers, indicating e.g. inflammation or activation of the renin-angiotensin, aldosterone system (RAAS).
- increased risk of CKD (susceptibility biomarkers), such as age, gender, ethnicity, genetic polymorphisms, or environmental factors such as low birth weight or exposure to toxins.

- kidney injury biomarkers, such as NGAL, KIM-1, FABP, uromodulin or TGF- $\beta$.

- evidence of loss of GFR (markers of early loss of GFR), such as creatinine or cystatin $\mathrm{C}$.

In addition to the aforementioned phenotype of premature senescence and cachexia associated with advanced $\mathrm{CKD}$, an important and characteristic for pediatric age aspects of renal failure are early growth and nutrition disorders requiring major therapeutic challenges. ZAG (zinc- $\alpha 2$-glycoprotein) - adipokine, which consists of one glycopolypeptide chain made up of 278 amino acids with a molecular mass of $43 \mathrm{kDa}$, may participate in the mechanism of malnutrition in CKD as cachexia factor. ZAG induces lipolysis through cAMP and stimulation of adenyl cyclase, followed by activation of hormone-dependent lipase (HSL) (Bing et al. 2010, Bouchara et al. 2018). ZAG is produced and secreted by adipocytes and epithelial cells in different organs (Tada et al. 1991) and is simultaneously a member of the family of proteins of the major class I tissue compatibility complex. Leal et al. in their study observed the relationship between ZAG and factors of inflammatory response and atherogenic molecules: adiponectin, LDL, TNF-a, interleukin-6 in adult CKD patients on hemodialysis (Leal et al. 2012). Adipose tissue dysfunction resulting in enhanced production of proinflammatory factors has a direct impact on the endothelium with the increase its adhesiveness to monocytes (Poledne et al. 2015). The transmembrane protein of the endoplasmic reticulum known as lipase maturation factor 1 (LMF1) is necessary for the secretion and normal enzymatic activity of LPL, hepatic lipase (HL) and endothelial lipase (EL) (Babilonia-Rosa and Neher 2014) which protects again malnutritioninflammation-atherosclerosis syndrome, frequently described in CKD patients (Mak et al. 2011).

The aim of this study is to evaluate mentioned above new markers and their potential importance in chronic kidney disease in children including the problems of enhancing lipid disturbances and cachexia. We hypothetise if ZAG (Zinc- alfa2 glycoprotein)/LMF (Lipid Mobilizing Factor) and LMF1 (Lipase Maturation Factor) could play the role in worsening of these conditions. 


\section{Material}

The study included 59 children and adolescents aged $10.7 \pm 5.0$ years ( 2.4 to 18 years) with chronic kidney disease, diagnosed and treated in the Department of Children's Nephrology and the Children's Nephrology Outpatient Clinic of Independent Public Clinical Hospital No. 1 in Zabrze, SUM in Katowice, Poland. Children and adolescents who were included in the study group did not experience inflammation or infectious disease during the month preceding the sampling. Among the causes of CKD were: congenital kidney and urinary tract defects (CAKUT) in 33 children (55.9\%), in 12 (20.3\%) - cystic kidney disease and nephronophthisis, in 6 (10.2\%) glomerulonephritis, in $4(6.8 \%)$ tubulointerstitial nephritis / drug-induced kidney damage, in 2 (3.4\%) hemolytic uremic syndrome, in 2 (3.4\%) - tubulopathies. Eleven children were treated with renal replacement therapy. In order to conduct analyzes, the studied group of children with CKD was divided into the following subgroups: by sex, age, and stage of kidney disease. The study group had been interviewed on the subject past medical history and a physical examination performed, including anthropometric measurements and blood pressure evaluation. Body mass index (BMI) was calculated using the formula $(\mathrm{BMI}=$ body weight $(\mathrm{kg}) /$ height $\left.\left(\mathrm{m}^{2}\right)\right)$. The estimated glomerular filtration rate (eGFR) was calculated according to the Schwartz formula $\left(\mathrm{ml} / \mathrm{min} / 1.73 \mathrm{~m}^{2}\right)$ (Mian and Schwartz 2017). Left ventricular mass index (LVMI) was calculated from LVM indexed to height (in $\mathrm{m}$ ) raised to the power of 2.7 (de Simone et al. 1992), where $\operatorname{LVM}(\mathrm{g})=0.8 \times\{1.04 \mathrm{x}$ $(($ LVEDD+PWT+IVST)3 - (LVEDD)3) + 0.6 $\}$ according to Devereux equation (Devereux et al. 1986).

The control group included outpatient patients treated for bedwetting or preparing for "one day" surgery who agreed to additional examinations, taken during routine tests.

Anthropometric measurements as well as age and blood pressure values of the examined children and children from the control group are presented in Table 1. The average age, body weight, height and BMI in the examined and control groups did not differ significantly. The value of SDS for body weight and height was significantly higher in the group of healthy children. The study was approved by the Bioethical Committee of the Silesian Medical University in Katowice (Resolution No. KNW / 0022 / KB1 / 75/16 of 5.07.2016). Written informed consent of the parents / guardians of the examined person and in the case of adolescents over 16 years of age - the examined patient was obtained for participation in the study.

Table 1. Clinical characteristics of evaluated children (CKD and control group)

\begin{tabular}{|c|c|c|c|c|c|c|}
\hline \multirow{2}{*}{ Parameter } & \multicolumn{3}{|c|}{ CKD group } & \multicolumn{3}{|c|}{ Control Group } \\
\hline & $\begin{array}{l}\text { Whole group } \\
\quad(n=59)\end{array}$ & $\begin{array}{c}\text { Girls } \\
(n=22)\end{array}$ & $\begin{array}{c}\text { Boys } \\
(n=37)\end{array}$ & $\begin{array}{l}\text { Whole group } \\
\quad(n=34)\end{array}$ & $\begin{array}{c}\text { Girls } \\
(n=11)\end{array}$ & $\begin{array}{c}\text { Boys } \\
(n=23)\end{array}$ \\
\hline Age (years) & $10.7 \pm 5.0$ & $12.1 \pm 5.1$ & $9.9 \pm 4.8$ & $9.8 \pm 4.3$ & $10.1 \pm 4.6$ & $9.7 \pm 4.2$ \\
\hline Height $(\mathrm{cm})$ & $134.3 \pm 26.6$ & $136.1 \pm 25.1$ & $133.3 \pm 27.8$ & $140.3 \pm 25.0$ & $138.2 \pm 21.3$ & $141.3 \pm 27.0$ \\
\hline Height SDS & $-1.3 \pm 1.2^{\#}$ & $-1.57 \pm 1.44^{a}$ & $-1.13 \pm 1.04^{b}$ & $0.25 \pm 1.07$ & $0.16 \pm 0.88$ & $0.29 \pm 1.16$ \\
\hline Body weight (kg) & $35.3 \pm 18.8$ & $35.5 \pm 16.2$ & $35.2 \pm 20.4$ & $36.9 \pm 20.0$ & $35.5 \pm 17.3$ & $37.6 \pm 21.5$ \\
\hline Body weight SDS & $-0.9 \pm 1.3^{\#}$ & $-1.3 \pm 1.41^{a}$ & $-0.68 \pm 1.23^{b}$ & $-0.08 \pm 1.05$ & $-0.04 \pm 1.11$ & $-0.1 \pm 1.04$ \\
\hline$B M I\left(k g / m^{2}\right)$ & $18.0 \pm 4.0$ & $17.9 \pm 3.6$ & $18.0 \pm 4.2$ & $17.3 \pm 3.7$ & $17.4 \pm 3.4$ & $17.2 \pm 3.9$ \\
\hline$B M I S D S$ & $-0.3 \pm 1.1$ & $-0.47 \pm 1.06$ & $-0.18 \pm 1.09$ & $-0.34 \pm 1.19$ & $-0.17 \pm 1.12$ & $-0.41 \pm 1.24$ \\
\hline$S B P(m m H g)$ & $111.8 \pm 14.3$ & $112.1 \pm 13.0$ & $111.7 \pm 15.1$ & $114.3 \pm 12.1$ & $108.8 \pm 10.6$ & $116.9 \pm 12.1$ \\
\hline$S B P S D S$ & $1.0 \pm 1.3$ & $0.96 \pm 1.04$ & $1.04 \pm 1.42$ & $1.06 \pm 1.04$ & $0.66 \pm 1.05$ & $1.25 \pm 1.0$ \\
\hline$D B P(m m ~ H g)$ & $67.1 \pm 11.8$ & $68.9 \pm 13.2$ & $66.1 \pm 11.0$ & $71.2 \pm 10.3$ & $69.4 \pm 7.6$ & $72 \pm 11.4$ \\
\hline$D B P S D S$ & $0.7 \pm 1.1$ & $0.73 \pm 1.25$ & $0.65 \pm 0.98$ & $0.95 \pm 0.93$ & $0.81 \pm 0.62$ & $1.02 \pm 1.05$ \\
\hline MAP (mm Hg) & $82 \pm 11.6$ & $83.3 \pm 12.4$ & $81.3 \pm 11.1$ & $85.5 \pm 9.1$ & $82.5 \pm 6.3$ & $87.0 \pm 9.9$ \\
\hline
\end{tabular}

Data are presented as mean \pm standard deviation. CKD - chronic kidney disease; BMI - body mass index; SDS- standard deviation score. ${ }^{\#} p<0.05$ total $C K D$ vs. control group, ${ }^{a} p<0.05$ girls with CKD vs. girls from control group, ${ }^{b} p<0.05$ boys with CKD vs. boys from control group 


\section{Methods}

Laboratory tests performed in patients with chronic kidney disease were as follows: morphology, serum creatinine, urea, uric acid, total protein, albumin, iron, total iron binding capacity (TIBC), ferritin, cholesterol, triglycerides. Performing the tests was associated with taking blood in the amount of about 3-5 $\mathrm{ml}$ and 50-100 $\mathrm{ml}$ of urine, during check-ups, to assess the concentration of proteins: ZAG andLMF1 in serum and urine. The blood sample was taken from a single injection. Sera and urine samples for determination were stored at -20 degrees until the time of determination. The determinations were made in the Department and Department of Medical and Molecular Biology in Zabrze, Faculty of Medical Sciences in Zabrze, SUM in Katowice, in accordance with the manufacturer's protocol using commercial kits.

\section{Determination of human Zinc-Alpha-2-Glycoprotein (ZAG) concentration}

ZAG concentrations in blood serum and urine were determined by the enzyme-linked enzyme method using the Bio-Vendor LLC test (BioVendor-Laboratorní medicínaa.s. Czech Republic) cat. No. RD 191093100R, according to the manufacturer's instructions. Detection of immunocomplexes was based on the reaction with a polyclonal anti-human ZAG antibody conjugated to horseradish peroxidase, followed by TMB solution as a substrate (TMB Substrate, slowkinetic, Sigma, USA).

\section{Determination of Lipase Maturation Factor 1 (LMF1) concentration}

LMF1 serum and urine concentrations were determined by enzyme immunoassay using the CloudClone Corp. test. (Houston USA) catalog number SEE177 $\mathrm{Hu}$, according to the manufacturer's instructions.

To determine the concentrations of the samples tested, a calibration curve was prepared using the standards contained in the kit. Absorbance readings were carried out using the Universal Microplate Spectrophotometer $\mu Q U A N T$ from BIO-TEK INC (Bio-Tek World Headquarters, California, USA), at $450 \mathrm{~nm}$ for LMF1 and $620 \mathrm{~nm}$ for ZAG2, and the results were developed using the KCJunior computer program (Bio-Tek, USA). The sensitivity of the kit for ZAG2 was $0.673 \mathrm{ng} / \mathrm{ml}$, the intraserial error $4.7 \%$ and the extracurricular error $6.6 \%$. The sensitivity of the kit for LMF1 was $0.055 \mathrm{ng} / \mathrm{ml}$, intra-serial error $<10 \%$ and extra-serial error $<12 \%$.

\section{Statistical analysis}

The database was prepared in a Microsoft Excel spreadsheet. STATISTICA software licensed for ver. 10.0 (StatSoft Inc, Tulsa, USA). The level of statistical significance was assumed at $p<0.05$. As parameters of descriptive statistics, the arithmetic mean, median, minimum and maximum values, lower and upper quartiles and standard deviation were selected. The compliance of their distributions with the normal distribution was checked for all parameters using the Shapiro-Wilk test. For variables with normal distribution, the parametric test was used ( $t$ test for independent variables in comparative analyzes and Pearson's test for correlation analyzes). For other variables, a nonparametric test was used (Mann-Whitney $U$ test for comparisons and Spearman rank correlation test for correlation analyzes).

\section{Results}

Table 2 presents the results of laboratory tests in the group of children with CKD. There were no differences between girls and boys. The concentration of albumin, total protein, PTH-1-84, total vitamin D, total cholesterol, HDL cholesterol, creatinine and urea, hemoglobin differed in the study groups of predialysis children and children on RRT. The mean value of serum creatinine level in healthy children was $61.4 \pm 17.3 \mu \mathrm{mol} / \mathrm{l}$ and eGFR $89.3 \pm$ $24.7 \mathrm{ml} / \mathrm{min} / 1.73 \mathrm{~m}^{2}$ and they were significantly different than in CKD group $(\mathrm{p}<0.0001)$. The mean left ventricular mass index (LVMI) in whole study group was 33.6 \pm $13.3 \mathrm{~g} / \mathrm{m}^{2,7}$, and did not differ between children treated conservatively and on dialysis $(33.8 \pm 14.2$ vs. $32.6 \pm$ 8.8 respectively, $\mathrm{p}=0.3576)$. The mean ejection fraction (EF) in whole CKD children was $69.3 \pm 4.3 \%$ and was not different in predialysis and dialyzed children (69.5 \pm 4.2 vs. $68.1 \pm 4,6$ respectively, $\mathrm{p}=0.3134$ ). Table 3 illustrates $\mathrm{ZAG}$ and LMF1 levels in children with CKD depending on sex and type of therapy. Compared with healthy children, serum and urine ZAG levels were higher in children with CKD. A similar relationship was obtained in the comparison of girls and boys between the above groups. In our studies, we showed a reduced concentration of LMF1 in both serum and urine in children with CKD. We compared the values of ZAG and LMF1 levels also in children below 10 years of age and above 10 . There were no differences between younger and older children (data not shown). There were no differences in ZAG and LMF1 levels according to sex between healthy girls and boys. 
Table 2. Biochemical parameters among the CKD group compared by sex and method of treatment.

\begin{tabular}{lccccc}
\hline Parameter & Whole group & Girls & Boys & Predialysis & RRT \\
\hline Serum albumin $(\mathrm{g} / \mathrm{l})$ & $43.8 \pm 7.2$ & $41.8 \pm 9.3$ & $45.0 \pm 5.4$ & $44.6 \pm 7.4^{\#}$ & $40.2 \pm 5.2$ \\
Total protein $(\mathrm{g} / \mathrm{l})$ & $69.1 \pm 6.6$ & $68.6 \pm 6.5$ & $69.4 \pm 6.8$ & $70.5 \pm 5.6^{\#}$ & $62.7 \pm 7.1$ \\
Parathyroid hormone $(\mathrm{pg} / \mathrm{ml})$ & $151.5 \pm 230.7$ & $206.3 \pm 324.8$ & $118.9 \pm 145.9$ & $81.0 \pm 66.9^{\#}$ & $459.2 \pm 399.6$ \\
Total cholesterol $(\mathrm{mmol} / \mathrm{l})$ & $4.6 \pm 1.0$ & $4.8 \pm 1.3$ & $4.5 \pm 0.8$ & $4.5 \pm 1.0^{\#}$ & $4.7 \pm 1.0$ \\
Cholesterol HDL $(\mathrm{mmol} / \mathrm{l})$ & $1.4 \pm 0.3$ & $1.3 \pm 0.3$ & $1.4 \pm 0.4$ & $1.4 \pm 0.3^{\#}$ & $1.2 \pm 0.3$ \\
Cholesterol LDL $(\mathrm{mmol} / \mathrm{l})$ & $2.5 \pm 0.8$ & $1.5 \pm 1.02$ & $2.4 \pm 0.7$ & $2.4 \pm 0.9$ & $2.5 \pm 0.6$ \\
Triglycerides $(\mathrm{mmol} / \mathrm{l})$ & $1.7 \pm 1.1$ & $1.9 \pm 1.3$ & $1.5 \pm 0.9$ & $1.5 \pm 1.0$ & $2.2 \pm 1.4$ \\
Creatinine $(\mu \mathrm{mol} / \mathrm{l})$ & $258.1 \pm 251.1$ & $327.8 \pm 300.8$ & $216.6 \pm 209.9$ & $158.7 \pm 118.1^{\#}$ & $691.7 \pm 214.4$ \\
Urea $(\mathrm{mmol} / \mathrm{l})$ & $12.35 \pm 6.3$ & $12.7 \pm 7.4$ & $12.2 \pm 5.6$ & $11.1 \pm 5.6^{\#}$ & $17.9 \pm 6.2$ \\
Hemoglobin $(\mathrm{g} / \mathrm{dl})$ & $12.3 \pm 2.1$ & $12.0 \pm 2.5$ & $12.5 \pm 1.9$ & $12.8 \pm 1.9^{\#}$ & $10.3 \pm 1.6$ \\
Ferritin $(\mu \mathrm{g} / \mathrm{l})$ & $108.2 \pm 219.3$ & $129.3 \pm 291.8$ & $95.2 \pm 163.6$ & $56.2 \pm 64.3$ & $330.3 \pm 433.6$ \\
CRP $(\mathrm{mg} / \mathrm{l})$ & $1.5 \pm 2.2$ & $1.2 \pm 1.2$ & $1.7 \pm 2.7$ & $1.5 \pm 2.4$ & $1.7 \pm 1.7$ \\
Phosphate $(\mathrm{mmol} / \mathrm{l})$ & $1.5 \pm 0.3$ & $1.5 \pm 0.3$ & $1.5 \pm 0.3$ & $1.5 \pm 0.3$ & $1.7 \pm 0.4$ \\
Vit. D $(\mathrm{mg} / \mathrm{ml})$ & $38.2 \pm 16.1$ & $34.5 \pm 16.6$ & $40.4 \pm 16.6$ & $40.8 \pm 16.4^{\#}$ & $27.0 \pm 8.6$ \\
eGFR $\left(\mathrm{ml} / \mathrm{min} / \mathrm{l} .73 \mathrm{~m}^{2}\right)$ & $35.4 \pm 21.2$ & $32.7 \pm 22.7$ & $30.7 \pm 20.5$ & $41.5 \pm 18.6$ & $/$ \\
\hline
\end{tabular}

Data are presented as mean \pm standard deviation. ${ }^{\#} \mathrm{P}<0.05$ predialysis vs. RRT, RRT- children on renal replacement therapy

Table 3. ZAG andLMF1 levels among the CKD group compared by gender and method of used treatment and in healthy children.

\begin{tabular}{|c|c|c|c|c|c|}
\hline Parameter & $\begin{array}{c}\text { Whole CKD } \\
\text { group }\end{array}$ & Girls & Boys & Predialysis & RRT \\
\hline \multicolumn{6}{|l|}{ Serum } \\
\hline $\begin{array}{l}\text { Human Zinc-Alpha-2- } \\
\text { Glycoprotein }(\mathrm{mg} / \mathrm{l})\end{array}$ & $56.4 \pm 19.9^{\#}$ & $55.7 \pm 18.2^{a}$ & $56.8 \pm 16.3^{b}$ & $55.3 \pm 14.6$ & $61.2 \pm 24.8$ \\
\hline $\begin{array}{l}\text { Lipase Maturation } \\
\text { Factor } 1(\mathrm{ng} / \mathrm{ml})\end{array}$ & $1.5 \pm 0.3^{\#}$ & $1.4 \pm 0.28^{a}$ & $1.5 \pm 0.3^{b}$ & $1.5 \pm 0.3$ & $1.5 \pm 0.3$ \\
\hline
\end{tabular}

\section{Urine}

\begin{tabular}{|c|c|c|c|c|c|}
\hline $\begin{array}{l}\text { Human Zinc-Alpha-2- } \\
\text { Glycoprotein ( } \mathrm{mg} / \mathrm{l})\end{array}$ & $66.8 \pm 20.2^{\#}$ & $65.7 \pm 24.4^{a}$ & $67.4 \pm 18.1^{b}$ & $66.9 \pm 19.4$ & $65.8 \pm 28.3$ \\
\hline \multirow[t]{2}{*}{$\begin{array}{l}\text { Lipase Maturation } \\
\text { Factor } 1(\mathrm{ng} / \mathrm{ml})\end{array}$} & $1.0 \pm 0.3^{\#}$ & $0.9 \pm 0.3^{a}$ & $1.0 \pm 0.3^{b}$ & $1.0 \pm 0.3$ & $1.1 \pm 0.2$ \\
\hline & $\begin{array}{l}\text { Whole healthy } \\
\text { group }\end{array}$ & Girls & Boys & & \\
\hline
\end{tabular}

\section{Serum}

Human Zinc-Alpha-2-

Glycoprotein ( $\mathrm{mg} / \mathrm{l})$

$\begin{array}{lll}25.9 \pm 7.5 & 24.2 \pm 5.1 & 26.6 \pm 8.4 \\ 3.5 \pm 0.5 & 3.5 \pm 0.7 & 3.5 \pm 0.5\end{array}$

$\begin{array}{llll}\text { Lipase Maturation } & 3.5 \pm 0.5 & 3.5 \pm 0.7 & 3.5 \pm 0.5 \\ \text { Factor } 1(\mathrm{ng} / \mathrm{ml}) & \end{array}$

\section{Urine}

$\begin{array}{lccc}\begin{array}{l}\text { Human Zinc-Alpha-2- } \\ \text { Glycoprotein }(\mathrm{mg} / \mathrm{l})\end{array} & 32.1 \pm 8.3 & 31.4 \pm 5.7 & 32.4 \pm 9.5 \\ \begin{array}{l}\text { Lipase Maturation } \\ \text { Factor } 1(\mathrm{ng} / \mathrm{ml})\end{array} & 2.1 \pm 0.9 & 2.2 \pm 1.1 & 2.0 \pm 0.8\end{array}$

Data are presented as mean \pm standard deviation. All comparisons between sex and mode of CKD treatment NS. RRT- children on renal replacement therapy. ${ }^{\#} p<0.0001$ whole CKD vs. control group, ${ }^{a} p<0.0001$ girls with CKD vs. girls from control group, ${ }^{b} p<0.0001$ boys with CKD vs. boys from control group 
In the conducted correlation analysis in the studied group of children with CKD, no relationship between the values of the analyzed markers ZAG and LMF1 and the values of anthropometric measurements, blood pressure measurements expressed as absolute values and SDS values were found. There was also no correlation between these markers and serum creatinine (except negative correlation of urinary ZAG $\mathrm{r}=-0.3005$, $\mathrm{p}=0.038$ ), albumin, cholesterol, triglycerides. Urine ZAG level correlated positively with eGFR in whole examined group and in predialysis children $(\mathrm{r}=0.2752, \mathrm{p}=0.046$; $\mathrm{r}=0.3189, \mathrm{p}=0.027$ respectively). Urine LMF1 correlated negatively with serum vitamin $\mathrm{D}$ concentration in whole examined group and in predialysis children $(\mathrm{r}=-0.3221$, $\mathrm{p}=0.019, \mathrm{r}=-0.3405, \mathrm{p}=0.018$ respectively). Serum LMF1 concentration correlated positively with vitamin $\mathrm{D}$ level in dialyzed patients $(\mathrm{r}=0.8268, \mathrm{p}=0.003)$.

\section{Discussion}

A review of the latest literature, including reports in adult patients with $\mathrm{CKD}$, allows us to state that ZAG is a promising indicator that finds application in diagnostic methods of chronic kidney disease (Woźny et al. 2019). Current data showed that adults with nephropathy in the course of type 2 diabetes mellitus with impaired renal function had significantly higher levels of ZAG determined in both urine and peripheral blood compared to the control group (Wang et al. 2016). In the group of children with CKD we analyzed, we obtained similar results which documents that selective kidney damage leads to an increase in ZAG concentration and also occurs in CKD on the basis of e.g. malformations of the kidneys and urinary system, in which early kidney interstitial fibrosis occurs. Additionally in our study there was no correlation with the concentration of total cholesterol, triglycerides, HDL and LDL cholesterol, CRP and BMI. We have not confirmed the influence of ZAG on malnutrition in children with CKD. Contrary to our results, the concentration of ZAG in serum positively correlated with serum creatinine and eGFR in their results (Wang et al. 2016).

ZAG was also examined as the index of malnutrition in girls with anorexia nervosa and its serum concentration was higher as compared to control group. Jarzumbek concludes that it could play a role in exploitation of lipolysis products. In that group the values of ZAG correlated negatively with body weight and BMI opposing to our results (Jarzumbek 2017).
Pelletier et al. in the study on adult patients with CKD treated conservatively reported no correlation of plasma ZAG with decreasing eGFR (Pelletier et al. 2014). In examined by us children only urine concentration of ZAG correlated positively with eGFR in predialysis children and all children with CKD and negatively with serum creatinine concentration in predialysis children. It means that ZAG accumulation is caused by its reduced excretion with declining kidney function. The lack of the correlations of serum ZAG levels with eGFR in children with CKD may be due to the relatively short duration of CKD compared to adults who have been ill for many years and the small size of the group we study. Our study did not analyze the correlation of ZAG in urine with the albumin/creatinine index, however, all children except children with anuria presented explicit overt proteinuria.

Another interesting problem is the role of ZAG in cardiovascular complications as it was documented by Zhou et al. that ZAG could promote endothelial alteration and change the structure of vessels (Zhou and Qin 2012). $\mathrm{ZAG}$ is also considered as the factor contributing to hypertension (Zhu et al. 2014, Kurita et al. 2015). We have not confirmed the relationship of ZAG with blood pressure determinants and EF or LVMI, which could be the result of only mild involvement of cardiovascular system in children with CKD. Bouchara's et al. investigation performed in adult hemodialysis patient showed that ZAG was strong predictive factor of cardiovascular events but also was positively related to age which is consistent with our findings (Bouchara et al. 2018). They suggested that the lipolytic properties were mediated by local ZAG appearance in adipose tissue.

Lipoprotein lipase (LPL) plays a key role in lipid metabolism. This protein hydrolyses triglycerides for the distribution of free fatty acids to peripheral tissues. Biochemical deficiency of LPL activity is one of the well-known causes of hypertriglyceridemia underlying atherosclerosis, a complication already found in the early stages of CKD. Plengpanich et al. detected 2 common and 12 rare variants in the LMF1 gene responsible for LPL activity in 101 Thai patients with severe hypertriglyceridemia (Plengpanich et al. 2020).

At present, there are no data in the literature regarding the concentration of LMF1 protein in the population of adults and children with CKD and reports on its impact on lipid metabolism in patients with kidney damage. In our study, we showed a reduced concentration of LMF1 in both serum and urine in children with CKD, 
which confirms that lipid metabolism alteration starts early in children with CKD in whom other metabolic diseases were not detected.

However, we did not confirm significant correlations of serum LMF1 levels with the concentrations of determined lipid metabolism parameters and parameters of cardiac function. The lack of significant correlations may be caused by the low number of patients from the dialysis group in whom lipid metabolism disorders were more severe than in children with CKD treated conservatively. Moreover, we showed, that serum LMF1 concentration correlated positively with vitamin D level in dialyzed patients and both values were significantly low in this group. It was highlighted by Arfian et al. that application of vitamin D plays a role in attenuating vascular remodeling with upregulating endothelial nitrite oxide synthase (eNOS) expression in kidneys of patients with $\mathrm{CKD}$, thus having beneficial effect on the disease progression (Arfian et al. 2018).

In previous our manuscript on the role of FGF21 in children with CKD we also did not show the relationship of the examined marker with lipid metabolism (Gamrot et al. 2020).

We have either not document the difference in ZAG and LMF1 levels between children below 10 years old and adolescents with CKD. The subgroups were selected to investigate if there are any differences connected with puberty and acceleration of statural growth.

\section{Conclusion}

To conclude, elevated serum ZAG levels in children with CKD document that selective kidney damage results in the rise of ZAG concentration, however the specific role of this marker in malnutrition was not documented. Reduced LMF1 concentrations in children with $\mathrm{CKD}$, did not correlate with standard parameters used to assess lipid metabolism and severity of CKD. The usefulness of LMF1 as the marker of the disturbances of lipid metabolism in children with CKD was not proven. Further research is needed on larger groups of children with CKD to clarify the specific role of the above markers in this age population.

\section{Conflict of Interest}

There is no conflict of interest.

\section{Acknowledgements}

The study was financially supported by Scientific Grant No. KNW-1-076 /N /7 / K of the Silesian Medical University in Katowice.

\section{References}

ARFIAN N, KUSUMA MH, ANGGOROWATI N, NUGROHO DB, JEFFILANO A, SUZUKI Y, IKEDA K, EMOTO $\mathrm{N}$ : Vitamin D upregulates endothelin-1, ETBR, eNOS mRNA expression and attenuates vascular remodelling and ischemia in kidney fibrosis model in mice. Physiol Res 67 (Suppl 1): S137-S147, 2018. https://doi.org/10.33549/physiolres.933823

BABILONIA-ROSA MA, NEHER SB: Purification, cellular levels, and functional domains of lipase maturation factor 1. Biochem Biophys Res Commun 450: 423-428, 2014. https://doi.org/10.1016/j.bbrc.2014.05.136

BING C, MRACEK T, GAO D, TRAYHURN P: Zinc-a2-glycoprotein: an adipokine modulator of body fat mass? Int J Obes (Lond) 34: 1559-1565, 2010. https://doi.org/10.1038/ijo.2010.105

BOUCHARA A, DAN YI, PASTURAL M, GRANJON S, SELAG JC, LAVILLE M, ARKOUCHE W, PELLETIER S, FOUQUE D, SOULAGE CO, KOPPE L: Serum levels of the adipokine zinc-alpha2-glycoprotein (ZAG) predict mortality in hemodialysis patients. Kidney Int 94: 983-992, 2018. https://doi.org/10.1016/j.kint.2018.07.019

CARRERO JJ, STENVINKEL P, FELLSTRÖM B, QURESHI AR, LAMB K, HEIMBÜRGER O, BÁRÁNY P, RADHAKRISHNAN K, LINDHOLM B, SOVERI I, NORDFORS L, SHIELSPG: Telomere attrition is associated with inflammation, low fetuin-A levels and high mortality in prevalent haemodialysis patients. J Intern Med 263: 302-312, 2008. https://doi.org/10.1111/j.1365-2796.2007.01890.x 
COLLINS AJ, FOLEY R, HERZOG C, CHAVERS B, GILBERTSON D, ISHANI A, KASISKE B, LIU J, MAU LW, MCBEAN M, MURRAY A, PETER WS, XUE J, FAN Q, GUO H, LI Q, LI S, PENG Y, QIU Y, ROBERTS T, SKEANS M, SNYDER J, SOLID C, WANG C, WEINHANDL E, ZAUN D, ZHANG R, ARKO C, CHEN SC, DALLESKA F, DANIELS F, DUNNING S, EBBEN J, FRAZIER E, HANZLIK C, JOHNSON R, SHEETS D, WANG X, FORREST B, CONSTANTINI E, EVERSON S, EGGERS P, AGODOAL: Excerpts from the United States Renal Data System 2007 annual data report. Am J Kidney Dis 51 (Suppl 1): S1-S320, 2008. https://doi.org/10.1053/j.ajkd.2007.11.001

DE SIMONE G, DANIELS SR, DEVEREUX RB, MEYER RA, ROMAN MJ, DE DIVITIIS O, ALDERMAN MH: Left ventricular mass and body size in normotensive children and adults: Assessment of allometric relations and impact of overweight. J Am Coll Cardiol 20: 1251-1260, 1992. https://doi.org/10.1016/07351097(92)90385-Z

DEVEREUX RB, ALONSO DR, LUTAS EM, GOTTLIEB GJ, CAMPO E,SACHS I, REICHEK N: Echocardiographic assessment of left ventricular hypertrophy: Comparison to necropsy findings. Am J Cardiol 57: 450-458, 1986. https://doi.org/10.1016/0002-9149(86)90771-X

GAMROT Z, ADAMCZYK P, ŚWIĘTOCHOWSKA E, ROSZKOWSKA-BJANID D, GAMROT J, SZCZEPAŃSKA M: Fibroblast growth factor 21 (FGF21) in children and adolescents with chronic kidney disease. Physiol Res 69: 451-460, 2020. https://doi.org/10.33549/physiolres.934307

GROOTHOFF JW, GRUPPEN MP, OFFRINGA M, HUTTEN J, LILIEN MR, VAN DE KAR NJ, WOLFF ED, DAVIN JC, HEYMANS HS: Mortality and causes of death of end-stage renal disease in children: a Dutch cohort study. Kidney Int 61: 621-629, 2002. https://doi.org/10.1046/j.1523-1755.2002.00156.x

JARZUMBEK A: The evaluation of serum MIC-1 and ZAG/LMF in girls with anorexia nervosa. PhD Thesis, Medical University of Silesia in Katowice, 2017.

KOOMAN JP, BROERS NJ, USVYAT L, THIJSSEN S, VAN DER SANDE FM, CORNELIS T, LEVIN NW, LEUNISSEN KM, KOTANKO P: Out of control: accelerated aging in uremia. Nephrol Dial Transplant 28: 48-54, 2013. https://doi.org/10.1093/ndt/gfs451

KOOMAN JP, KOTANKO P, SCHOLS AM, SHIELSPG, STENVINKEL P: Chronic kidney disease and premature ageing. Nat Rev Nephrol 10: 732-742, 2014. https://doi.org/10.1038/nrneph.2014.185

KURITA S, TAKEUCHI K, HAYASHI Y, UEYAMA H, ZANKOV DP, PANG X, OTSUKA T, OHKUBO I, OGIKUBO O, OGITA H: Significance of serum Zn- $\alpha 2$-glycoprotein for the regulation of blood pressure. Hypertens Res 38: 244-251, 2015. https://doi.org/10.1038/hr.2014.165

LEAL VO, LOBO JC, STOCKLER-PINTO MB, FARAGE NE, VELARDE GC, FOUQUE D, LEITE M JR, MAFRA D: Is zinc-a2-glycoprotein a cardiovascular protective factor for patients undergoing hemodialysis? Clin Chim Acta 413: 616-619, 2012. https://doi.org/10.1016/j.cca.2011.12.002

MCDONALD SP, CRAIG JC: Long-term survival of children with end-stage renal disease. N Engl J Med 350: 2654-2662, 2004. https://doi.org/10.1056/NEJMoa031643

MAK RH, IKIZLER AT, KOVESDY CP, KOVESDY CP, RAJ DS, STENVINKEL P, KALANTAR-ZADEH K: Wasting in chronic kidney disease. J Cachexia Sarcopenia Muscle 2: 9-25, 2011. https://doi.org/10.1007/s13539-011-0019-5

MIAN AN, SCHWARTZ GJ: Measurement and estimation of glomerular filtration rate in children. Adv Chronic Kidney Dis 24: 348-356, 2017. https://doi.org/10.1053/j.ackd.2017.09.011

NATIONAL KIDNEY FOUNDATION.K/DOQI Clinical Practice Guidelines for Chronic Kidney Disease: Evaluation, Classification, and Stratification. February Supplement 1. Am J Kidney Dis (Suppl 1) 39: S1-S266, 2002.

OH J, WUNSCH R, TURZER M, BAHNER M, RAGGI P, QUERFELD U, MEHLS O, SCHAEFER F: Advanced coronary and carotid arteriopathy in young adults with childhood-onset chronic renal failure. Circulation 106: 100-105, 2002. https://doi.org/10.1161/01.CIR.0000020222.63035.C0

PELLETIER CC, KOPPE L, ALIX PM, KALBACHER E, CROZE ML, HADJ-AISSA A, FOUQUE D, GUEBREEGZIABHER F, SOULAGE CO: The relationship between renal function and plasma concentration of the cachectic factor zinc-alpha2-glycoprotein (ZAG) in adult patients with chronic kidney disease. PLoS ONE, 9, e0103475, 2014. https://doi.org/10.1371/journal.pone.0103475 
PLENGPANICH W, MUANPETCH S, CHAROEN S, KIATEPRUNGVEJ A, KHOVIDHUNKIT W: Genetic and functional studies of the LMF1 gene in Thai patients with severe Hypertriglyceridemia. Mol Genet Metab Rep 23; e100576, 2020. https://doi.org/10.1016/j.ymgmr.2020.100576

POLEDNE R, KRÁLOVÁLESNÁI,ČEJKOVÁ S: Adipose tissue and atherosclerosis. Physiol Res 64 (Suppl. 3): S395-S402, 2015. https://doi.org/10.33549/physiolres.933152

SHLIPAK MG, DAY EC: Biomarkers for incident CKD: a new framework for interpreting the literature. Nat Rev Nephrol 9: 478-483, 2013. https://doi.org/10.1038/nrneph.2013.108

STENVINKELP, LARSSON T: Chronic kidney disease: a clinical model of premature aging. Am J Kidney Dis 62 : 339-351, 2013. https://doi.org/10.1053/j.ajkd.2012.11.051

TADA T, OHKUBO I, NIWA M, SASAKI M, TATEYAMA H, EIMOTO TJ: Immunohistochemical localization of Zn-alpha 2-glycoprotein in normal human tissues. Histochem Cytochem 39: 1221-1226, 1991. https://doi.org/10.1177/39.9.1918940

WANG Y, LI YM, ZHANG S, ZHAO JY, LIU CY: Adipokine zinc-alpha-2-glycoproteinas a novel urinary biomarker presents earlier than micro albuminuria in diabetic nephropathy. J Int Med Res 44: 278-286, 2016. https://doi.org/10.1177/0300060515601699

WOŹNY ŁA, MORAWIECKA-PIETRZAK M, JASZCZURA M, ZIORA K, GRZESZCZAK W: The new adipokine zinc- $\alpha 2$-glycoprotein (ZAG) as a link between adipose tissue and kidney? Endokrynol Pol 70: 171-189, 2019. https://doi.org/10.5603/EP.a2018.0085

ZHOU J, QIN G. Adipocyte dysfunction and hypertension. Am J Cardiovasc Dis, 2, 143-149, 2012.

ZHU HJ, WANG XQ, PAN H, GONG FY, ZHANG DX, LI NS, WANG LJ, YANG HB: Serum levels of the adipokine zinc-2-glycoprotein are decreased in patients with hypertension. ISRN Endocrinology, e374090, 2014. https://doi.org/10.1155/2014/374090 